\title{
BRITISH JOURNAL OF
}

\section{ANAESTHETIC \& RECOVERY NURSING}

\section{CONTENTS}

FROM THE PRESIDENT

- Letter from the President Mark Radford

FROM THE CHAIRMAN

- Letter from the Chair Manda Dunne

EDITORIAL

- Letter from the Editor Jessica Inch

\section{ORIGINAL ARTICLES}

- The Preoperative Evaluation of Cardiovascular Functional Reserve in Patients Undergoing Major Arthroplasty Surgery

Corrine Jenkinson
- A Comparative Look at Forehead and Tympanic Temperatures: An Audit Report

Ishwori Thakuri

\section{CONFERENCE REPORT}

- The American Society of Peri-Anaesthesia Nurses Annual Conference, Washington DC, USA

Jessica Inch

INTERVIEW

- Your Local Anaesthetic/Recovery Unit: What Makes it Special?

Melissa Mellis 
https://doi.org/10.1017/S1742645609990064 Published online by Cambridge University Press 


\section{BARNA}

British Anaesthetic and Recovery Nurses Association www.barna.co.uk
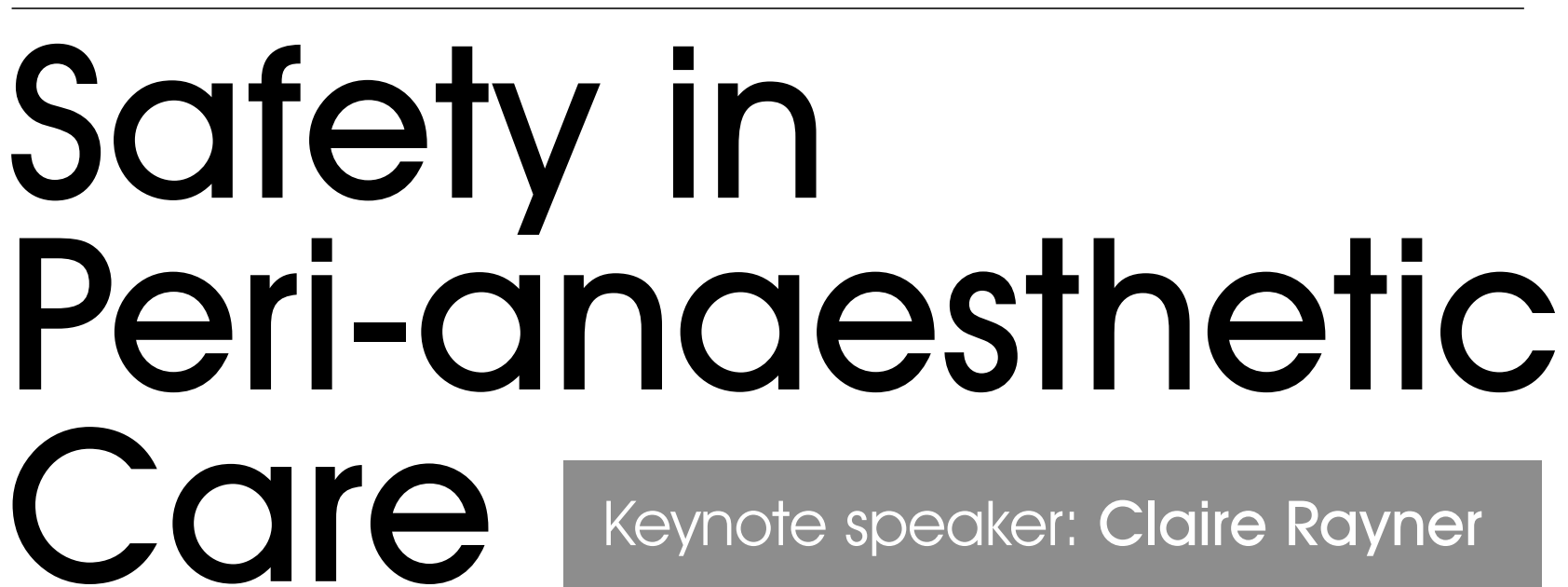

\section{Keynote speaker: Claire Rayner}

\section{BARNA Annual Conference, AGM and Exhibition}

Devonport House, Greenwich, London 5th June 2009.

\section{Supported by Dräger}

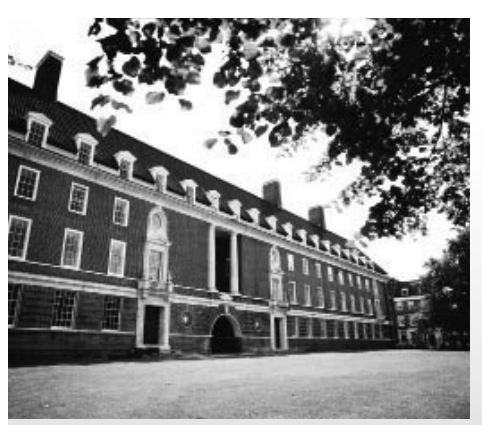

$£ 150$

for members,

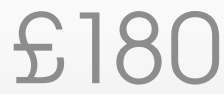

for non-members

Open to Anaesthetic and Recovery Nurses, ODPs and other professionals with an interest in this speciality.

Topics to include:

- Paediatric Fluid Replacement

- Control of blood pressure in the post anaesthetic patient

- The child is NOT a small adult

- Anaphylaxis

- Talking transfusion: Who, When and What else is there?

- Safe intravenous delivery

- Tips and Tricks in Cenral Vascular Catheterisation

- Safe surgery saves lives

- Patient's Experience \& Perspectives with Medical accidents

- What you should know about Medicines and Healthcare products Regulatory Agency

- Perianaesthesia data elements and electronic documentation

- Thromboprophylaxis 
08:00-09:00 Registration, Coffee and Exhibition Ground and First floors in De Vere Venue

09:00-09:45 Welcome from Manda Dunne, BARNA Chair. Key note speech: Mrs Claire Rayner, Celebrity Speaker

09:45-10:25 Thromboprophylaxis

Dr Alexander Kidd, SWELOC, Epsom

Safe IV delivery

Dr Tim Craft, Anaesthetic Medical Supplies

10:30-10:55 Coffee in the Coffee Lounge and Exhibition in Nelson and Hamilton Rooms

11:00-11:40

Dr. Laurence Boss

Eastbourne Hospital

Tips and Tricks in Central Vascular Catheterisation

Dr Evangelous Konstantinou, Assistant Professor in Nurse Anaesthesiology, University of Athens

11:45-12:25 $\quad$ BP $=$ CO x SVR Applied physiology in the Management

Safe Surgery Saves Lives

of Post Anaesthetic Hypotension

Joan Russell, Head of Anaesthesia and Surgery,

Katie Scales, Consultant Nurse Critical Care, Imperial

Patient Safety Division NPSA (National Patient Safety College Healthcare NHS Trust

Agency)

12:30-14:00 Lunch in the Coffee Lounge Ground Floor, Exhibition in Nelson and Hamilton Rooms. AGM for BARNA members in the Drake Room at 13.30

14:00-14:40 The Child is NOT a Small Adult

Lois Schick, Immediate Past President ASPAN

(American Society of PeriAnesthesia Nurses)

Patient's Experience \& Perspectives

Peter Walsh, Chief Executive, Action Against Medical Accidents

14:45-15:25 $\begin{aligned} & \text { Anaphylaxis } \\ & \text { Mark Radford, Divisional Director of Nursing (Surgery), }\end{aligned}$

University Hospitals Coventry and Warwickshire

What you should know about MHRA

Dr Christopher Earl, Nursing Advisor (Medicines and Healthcare products Regulatory Agency)

\begin{tabular}{ll} 
15:30-16:00 & Tea and Exhibition \\
\hline 16:00-16:40 & Talking Transfusion: Who, When and What else is there?
\end{tabular}

Emma Stalker, Transfusion Liaison Nurse NHSBT

Perianaesthesia Data Elements and Electronic

Documentation

Denise O'Brien, Perianaesthesia Clinical Nurse

Specialist, University of Michigan Hospital

16:45-17:00 Final Close by Mark Radford

Registration Form Please feel free to photocopy this form Complete a form for EACH Candidate

\section{Total Fees Payable}

By Cheque - Please make cheques payable to BARNA

A cheque for $\mathbf{f}$

is enclosed

By invoice - Purchase order no:

Please send an invoice to:

Postcode:

Payment by BACS - ensure a remittance advice is sent

Barclays Bank - Sort code: 20-84-17 Account no: 90210978.
Full Name:

Job title:

Department:

Organisation:

Email:

Address:

Postcode:

I have read and understood the Conference Registration Terms \& Conditions

Signed:

Date:

Return completed forms \& payment to: BARNA Services, c/o M\&K Update Ltd, The Old Bakery, St. John's Street, Keswick, Cumbria, CA12 5AS

Registration:

Please send your completed registration form with full payment to: BARNA Conference, c/o M\&K Update Lłd

The Old Bakery, Keswick, Cumbria, CA12 5AS

Alternatively, you can fax your completed registration form to 01768781099 . You will not be registered for this event unless payment or correct invoicing delalls accompanies your application. copplican we held provisionally.

Special discount rates

Are available to BARNA members only.

Payment if registering for yourself

Payment is to be made at the time of booking by cheque payable to

Payment is to be made at the time of booking by cheque payable to
BARNA.

If registering on behalf of others or for your organisation We require a payment with your application or we can accept a purchase order number (finance/supplies departments) along with the full name and address of the person to be invoiced - you must have their permission before offering this.

Paying an invoice

Payment is due within 30 days of the invoice date, which will be issued at the time of booking or ordering. There is a charge for late payment $8 \%$ of the total invoice amount.

Payment by BACS

Please ensure a remittance advice is sent. Barclays Bank - Sort code: 20-84-17 Account no: 90210978
Cancellations:

Cancellations received twenty eight days before the start of the event will be refunded, minus a $25 \%$ administration fee.

Regrettably, no refunds can be processed after this date. Places can be substituted at any time with the prior knowledge and agreement of M\&K substill Full payment will be due from delegates who 28 days of the conference start or who fail to attend.

Travel and accommodation

You are advised NOT to book travel tickets or accommodation until you have received written joining details, BARNA will not reimburse these costs.

Further Information: BARNA Services, c/o M\&K Update Ltd The Old Bakery, Keswick, Cumbria, CA12 5AS Tel: 01768773030 Fax: 01768781099 barna@mkupdate.co.uk 


\section{CAMBRIDGE JOURNALS}

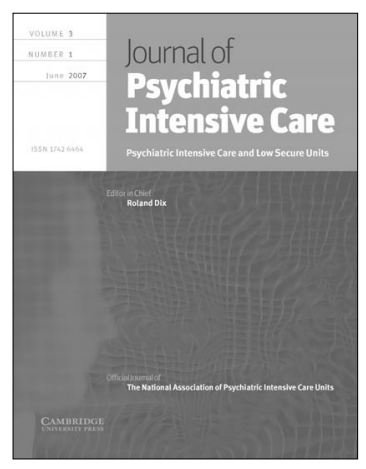

Journal of Psychiatric Intensive Care is available online at

journals.cambridge.org/jpi

To subscribe contact

Customer Services

\section{in Cambridge:}

Phone +44 (0)1223 326070

Fax +44 (0)1223 325150

Email journals@cambridge.org

in New York:

Phone (845) 3537500

Fax (845) 3534141

Email

subscriptions_newyork@cambridge.org
Journal of Psychiatric Intensive Care

Published for The National Association of Psychiatric Intensive Care Units

\section{Editor-in-Chief}

Roland Dix, Wotton Lawn Hospital, Gloucester, UK Deputy Editor

Jim Laidlaw, Wotton Lawn Hospital, Gloucester, UK

The Journal of Psychiatric Intensive Care is devoted to issues affecting the care and treatment of people with mental disorder who manifest severely disturbed mental or behavioural functioning. It serves the interest of all professionals concerned with these topics.

Price information is available at journals.cambridge.org/jpi

\section{Free email alerts}

Keep up-to-date with new material sign up at journals.cambridge.org/register 
https://doi.org/10.1017/S1742645609990064 Published online by Cambridge University Press 
https://doi.org/10.1017/S1742645609990064 Published online by Cambridge University Press 